\title{
The Role Of Islamic Business Ethics In The Relationship Between Adaptability And The Business Performance Of Syariah Financial Institutions
}

\author{
Agus Putranto', M. Trihudiyatmanto ${ }^{2}$ \\ 1,2 Universitas Sains Al-Qur'an (UNSIQ) Jawa Tengah, Indonesia. \\ agusp@unsiq.ac.id
}

\begin{abstract}
Purpose - This study was to analyze how much influence adaptability has on businessperformance. The variablesstudiedwere independentvariables consisting of adaptability variables and the dependentvariable was business performance with Islamic business ethics as a moderating variable.

Method - The research data were obtained from BMT Marhamah employees in Wonosobo Regency. Sampling from the population using the census sampling method. The data were collected using a survey method, namely the questionnaire was delivered and taken directly to the research object. Data analysis used the Structural Equation Modeling (SEM) test by checking the independent variables, moderating variables and dependent variables.
\end{abstract}

Result - From the research that has been done, it is found that adaptability has an effect on business performance at BMT Marhamah Wonosobo. Islamic business ethics affect business performance at BMT Marhamah Wonosobo. adaptability has an effect on business performance at BMT Marhamah Wonosobo with Islamic business ethics as a moderating variable. This means that Islamic business ethics moderates the relationship between adaptability and business performance at BMT Marhamah Wonosobo.

Implication - This study examines Micro Syariah Financial Institutions in Indonesia.

Originality - There is a difference between theory and practice in Islamic Microfinance Institutions in Indonesia.

Keywords: Business Performance; Adaptability; Islamic Business Ethics. 
Agus Putranto, M. Trihudiyatmanto

\section{Introduction}

Islamic work ethic comes from Al-Qur'an and Hadith which emphasizes cooperation and always works hard which is one way to wash away sins. In addition, there is a belief that God will not test His servants beyond their abilities and believe that God will provide something more beautiful if we succeed in surpassing it. So that Islamic work ethics is here as a mediating variable that can strengthen or weaken performance.

The purpose of this study was to analyze how much influence adaptability has on business performance. The variables studied were independent variables consisting of adaptability variables and the dependent variable was business performance with Islamic business ethics as a moderating variable. This research is a preliminary research conducted at BMT Marhamah Wonosobo by developing from research that has been conducted by Susilo Toto Raharjo (2016) with the title "The effect of adaptability and human resource advantages on process performance to improve product quality performance and in small and medium enterprises. in Central Java". Then it was strengthened by research conducted by Felix Andhy Winata, at. el (2018). With the title "The influence of relationship quality and adaptability to the environment that affect competitive advantage and its implications for company performance (Study at PT. Aga Pratama)". And then looking at the research conducted by Azalila Noor Malasari (2019) entitled "The effect of adaptation ability and innovative work behavior on innovative output with environmental dynamics as a moderating variable (Studies on Micro, Small and Medium Enterprises in Semarang City). Stating that the variable of adaptability positively and significantly affects performance.

The development of this research was carried out by using SEM (Structural Equation Modeling) methodology to test the accuracy of the results which are more valid because testing by testing indicators with meansurement techniques will get more detailed results when compared to multiple regression analysis as in research that has been done by previous researchers. .To test the unmeasured variables, the researcher used the analytical test tool 
The Role Of Islamic Business Ethics In The ...

using SEM. If the variable is (observerb), the analysis tool is path analysis, but if the variable is in latent form (unobserverb), then using a structural equation model test tool (Structural Equation Modeling) or SEM (Ghozali, 2016).

Based on the information and available data and supported by adequate opportunities, BMT Marhamah Wonosobo was chosen. The establishment of BMT aims to manage public finances and help improve the regional economy by providing credit to small entrepreneurs. In this study, the researcher wanted to find out whether in Islamic banking activities where the majority of Muslims act using Islamic work ethics as often said by the community that religion is the foundation of human life, whether in work, family, or society.

From what is explained above, it can be seen that the problem in this research is how the influence of adaptability can affect business performance in the operational activities of BMT Marhamah Wonosobo. And how much influence does Islamic Business Ethics have on the relationship between the influence of Adaptation Ability and Business Performance in the operational activities of BMT Marhamah Wonosobo. Then we get the formulation of the main problem to be studied, namely the problem of Adaptability to Business Performance with Islamic Business Ethics as a moderating variable.

\section{Literature Review}

\section{Business Performance}

Business performance is an achievement resulting from the impact of various roles that function in an organization, Ferdinand, 2004 in (Purwanto \& Trihudiyatmanto, 2018). Performance measurement is useful for the wearer to provide feedback that helps managers identify problems and help solve them. The role of performance measurement itself in general is to monitor, as a communication tool, and as the basis for the reward system Ostrenga \& Harwood, 1992 in (Trihudiyatmanto \& Purwanto, 2018). Business performance is an important element of company performance in general because the performance of a company can be seen from its business performance so far. Business performance is a concept for measuring a 
Agus Putranto, M. Trihudiyatmanto

company's marketing achievement. Every company has an interest in knowing its achievements as a reflection of the success of its business in market competition.

\section{Adaptability}

Adaptation can simply be defined as an adjustment made in the course of a process. (Vickers and Sword, 2008). Adaptability shows the readiness and ability of individuals, groups of individuals or organizations to follow changes that occur. Adaptation is needed for companies due to changes that occur around the company. The success of adapting a company depends on (Múhlbacher et al, 1987): 1. The level of employee acceptance of the mission statement and strategic goals of companies. The conformity between the required social norms that employees must follow and the personal attitudes of these employees are related to these social norms. The adaptations made by the company will require individuals in the company to adapt continuously and the most problematic idea is that someone in the company is able to survive. or succeeding through the mere individual would probably seem natural. (Brown, 2003). On the other hand, the success of the company's adaptation is determined by the employee's ownership attitude towards the company. (Thompson et al, 2013), IT executive managerial capabilities (Heart et al, 2010). Conversely, organizational adaptability affects the organizational commitment of its employees (Liu et al, 2010).

\section{Islamic Business Ethics}

Karl Bath revealed in Fitria (2003), ethics (ethos) is comparable to morals (mos), both of which are philosophies about customs (Sitten). Sitte in German words indicates the mode (mode) of human behavior, the constant (kelumintuan) of human action. Therefore, in general ethics or morals is a philosophy, science or discipline concerning modes of human behavior or the constants of human action.

Based on the nature of justice, Syariah for Muslims serves as the source of a set of criteria to distinguish what is right (haq) and what is bad (batil). By 
The Role Of Islamic Business Ethics In The ...

using Syariah, not only brings individuals closer to God, but also facilitates the formation of a just society, in which individuals realize their potential and prosperity is meant for all.

Afzalurrahman (1995) in Fitria (2003) reveals that many verses in the Al Qur'an emphasize the importance of work. A person does not get anything, except what he has worked for (Surah An-Najm: 39). It is clearly stated in this verse that the only way to produce anything from nature is to work hard. The success and progress of humans on this earth depends on their efforts. The harder he works, the richer he will be. This principle is further explained in the following verses: For a man there are benefits from what he earns. And for women there is a part that they earn (Surah An-Nisa: 32). Nature does not recognize the separation of humans, between men and women, between black and white, even between Muslims and non-Muslims, each of them is given a reward for what he does.

\section{Relationship between Adaptability and Business Performance}

Research related to the effect of adaptation capability on performance has been carried out by many researchers. Susilo Toto Raharjo (2016) concluded that the adaptations made by small and medium companies have a relationship with performance. Felix Andhy Winata, at. El (2018) emphasizes that to build quality requires the ability / attitude to adapt to change. And then looking at the research conducted by Azalila Noor Malasari (2019) to build the quality needed is the ability to adapt and make changes to organizational culture and infrastructure.

H1: Adaptability has a positive effect on business performance.

\section{The Relationship between Adaptability to Performance and Islamic Business Ethics as a Moderation Variable}

Islamic Work Ethics can encourage individuals to put forth their best efforts and work hard. Because the inclusion of good intentions in work will give good results too. Work allows a person to be independent and generate concern for others, satisfaction and self-fulfillment (Ali, 2008). Unethical 
employee behavior allows employees to deviate from their previously agreed main duties. This is supported by previous research written by Tri Ramadhan Aji Saputra (2015) which states that the stronger the influence of Islamic Work Ethics, the stronger the relationship between adaptability and business performance, and vice versa, unethical behavior will weaken the effect of adaptability on business performance. Thus, the interaction between Adaptability and Islamic Business Ethics has a significant positive effect on Business Performance, so it can be concluded that the Islamic Business Ethics variable is a moderating variable.

H2: Islamic business Ethics affect business performance

H3: Islamic business Ethics are able to moderate the influence of Adaptability on business performance

deposits.

\section{Research Model}

Of the several factors that affect the business performance above, a research model is compiled as can be seen in the image below:

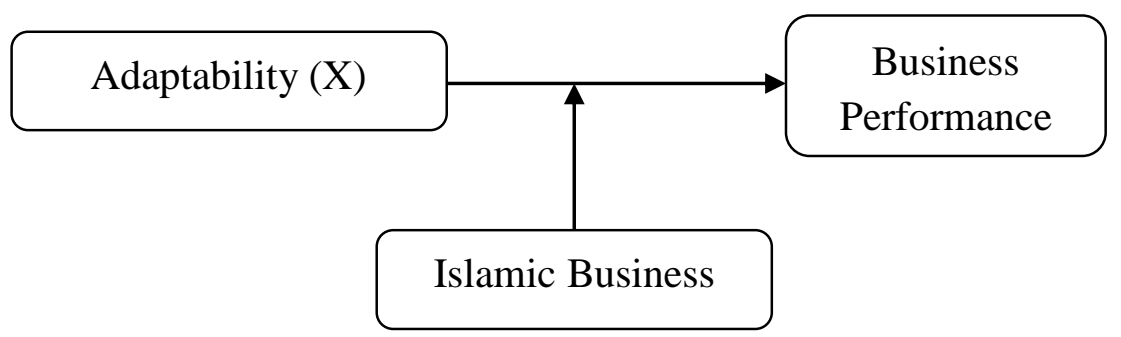

\section{Methods}

This research is a type of quantitative research, where the type of data used is in the form of numbers. According to Sugiyono (2012) quoted by Lubis (2018), quantitative research methods can be interpreted as a research method based on the philosophy of positivism, used to research on certain populations or samples. Meanwhile, Kasiram defines quantitative research as 
The Role Of Islamic Business Ethics In The ...

a process of finding knowledge that uses data in the form of numbers as a tool to analyze information about what you want to know (Lubis, 2018).

Population can be defined as the whole object of research consisting of humans, objects, animals, plants, symptoms, test scores, or events that are data sources that have certain characteristics in a study (Margono, 2004 in Lubis, 2018). In this study the population used was the employees of BMT Marhamah Wonosobo Regency.

Sempel is part of the population, or in mathematical terms it can be called a subset or subset of the population (Wahana, 2006). The sample of the population taken in this study were employees of BMT Marhamah Wonosobo Regency who met the requirements.

The ampling technique in this study was carried out using a nonprobability sampling method, where all elements in the population do not have the same opportunity to be selected as samples (Ferdinand, 2006), this is done because of time constraints. The sampling method used was purposive sampling technique, namely the sampling technique according to certain requirements or criteria. According to Ferdinand (2000) quoted in (Wuryanto, 2007) finding that for the SEM model, the sample size used is a range of 100200.

The model that will be used in this research is a model of causality or influence to test the proposed hypothesis, so the technique used is SEM (Structural Equation Models). The use of the SEM method in this study is because the SEM method can analyze data more comprehensively (Haryono, 2016). The SEM method can identify the dimensions of a construct and at the same time be able to measure the influence or degree of relationship between the factors that have identified the dimensions (Ferdinand, 2000) which is quoted in (Wuryanto, 2007).

According to (Haryono, 2016) the general structural equation model (SEM) has two parts, namely the Measurement Model and the Structural Model. The Measurement Model connects the observed/ manifest variable to the latent/ un-observerb variable through a confirmatory factor model. The 
Agus Putranto, M. Trihudiyatmanto

Structural Model connects between latent variables through a system of simultaneous equations.

\section{Results and Discussion}

\section{Research Overview}

Respondents in this study were employees of BMT Marhamah Wonosobo Regency, both men and women. This research was conducted by distributing questionnaires, questionnaires were distributed at the Head Office and several branches of BMT Marhamah, Wonosobo Regency. In this study, a sample of 105 respondents was taken. The data analysis method used is Structural Equation Modeling (SEM).

\section{Table 1. Validity Test Results of All Variables}

Source: Primary data processed, 2020

\begin{tabular}{cccc}
\hline Item & Correlation ( hitung) & R Tabel & Information \\
\hline K1 & 0,57049 & 0,300 & Valid \\
K2 & 0,65633 & 0,300 & Valid \\
K3 & 0,53760 & 0,300 & Valid \\
K4 & 0,57049 & 0,300 & Valid \\
KA1 & 0,43179 & 0,300 & Valid \\
KA2 & 0,62503 & 0,300 & Valid \\
KA3 & 0,66479 & 0,300 & Valid \\
KA4 & 0,64151 & 0,300 & Valid \\
KA5 & 0,57941 & 0,300 & Valid \\
KA6 & 0,59960 & 0,300 & Valid \\
EBI1 & 0,49020 & 0,300 & Valid \\
EBI2 & 0,50219 & 0,300 & Valid \\
EBI3 & 1,13389 & 0,300 & Valid \\
EBI4 & 0,33735 & 0,300 & Valid \\
EBI5 & 1,13389 & 0,300 & Valid \\
EBI6 & 0,35064 & 0,300 & Valid \\
EBI7 & 0,71072 & 0,300 & Valid \\
\hline
\end{tabular}


The Role Of Islamic Business Ethics In The ...

\section{Data Validity Test}

The validity test is a test that shows the extent to which the measuring instrument used will be able to measure what you want to measure and not measure anything else. In this study, the validity used is the validity test which shows how well the results obtained from the use of measures match the theory underlying the test design. It is said valid if $r$ count $>r$ table at the significant level of 0.05 .

The results of the validity test of the Adaptability variable, Islamic business ethics and business performance can also be seen from the value of $r$ count (Pearson Correlation) greater than $r$ table $(0.30)$, which means that all question items on all variables are valid, so that it can be used in further research.

\section{Reliability Test}

The measurement of reliability was done by using Cronbach's Alpha statistical test. In statistics Cronbach Alpha is a coefficient of internal consistency which is usually used to test reliability. The question indicator is said to be reliable if the Cronbach alpha value is $>0.60$. Following the reliability test results are shown in the table as follows.

Based on the table of reliability test results, Cronbach's Alpha value is obtained for each variable of Adaptability, Islamic business ethics and business performance. Reliability test results show that the variable used in this study has a Cronbach's Alpha value greater than 0.60. It can be interpreted that the instruments in this study can produce measurement concepts consistently and the bias that occurs can be minimized. Instruments or measuring instruments used in research have consistency as a measuring tool.

Table 2. Results of the Research Variable Reliability Test

\begin{tabular}{cccc}
\hline Variable & Cronbach's Alpha & Alpha & Information \\
\hline Performance & 0,821 & 0,60 & Reliable \\
Adaptability & 0,863 & 0,60 & Reliable \\
Islamic Business & 0,648 & 0,60 & Reliable \\
Ethics & & & \\
\hline
\end{tabular}

AL-ARBAH: Journal of Islamic Finance and Banking - Vol. 3 No. 1 (2021) 
Agus Putranto, M. Trihudiyatmanto

\section{Structural Equation Model}

The next analysis is a full model Structural Equation Model (SEM) analysis, after analyzing the unidimensionality level of the latent variable forming indicators tested by confirmatory factor analysis. Analysis of the results of data processing at the full model SEM stage was carried out by performing a suitability test and statistical test. The results of data processing for the full model SEM analysis are shown in the following figure:

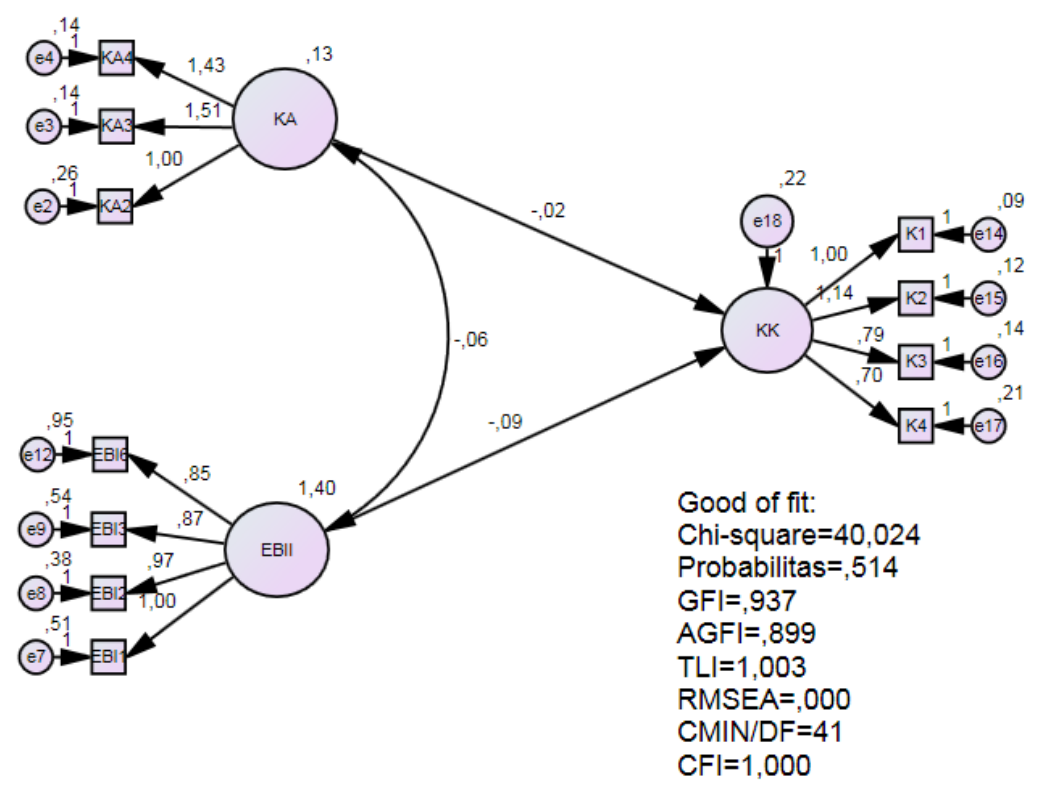

The probability value above 0.05 is 0.514 which indicates that the model is fit. The full output of the SEM Model in this study is as follows Table 3.

\section{Hypothesis Test}

The results of the full model used after the test conditions are carried out are as follows Table 4. 
The Role Of Islamic Business Ethics In The ..

Table 3. Output Full Model

\begin{tabular}{cccc}
\hline Goodness of fit index & Cut-off Value & Estimasi & Information \\
\hline Chi-square $(\chi 2)$ & Expected small & 40,024 & Good \\
Significance probability & $\geq 0,05$ & 0,514 & Good \\
RMSEA & $\leq 0,08$ & 0,000 & Good \\
GFI & $\geq 0,90$ & 0,937 & Good \\
AGFI & $\geq 0,90$ & 0,899 & Good \\
CMIN/DF & $\leq 3,00$ & 0,41 & Good \\
TLI & $\geq 0,95$ & 1,003 & Good \\
CFI & $\geq 0,95$ & 1,000 & Good \\
\hline
\end{tabular}

Based on Table 4 output results, the following hypothesis testing results are obtained:

H1: Adaptability has a positive effect on Business Performance at BMT Marhamah Wonosobo Regency. Based on the data from the data processing, it can be seen that the $\mathrm{P}$ value (probability) is $0.22<0.05$. This value indicates the results that meet the requirements of the provisions for $\mathrm{P}(0.05)$ so $\mathrm{H} 1$ in this study is accepted.

H2: Islamic Business Ethics has a positive effect on Business Performance at BMT Marhamah Wonosobo Regency. Based on the data from the results of data processing, it can be seen that the $\mathrm{P}$ value (probability) is $0.048<0.05$. This value indicates the results that meet the requirements of the provisions for $\mathrm{P}(0.05)$, then $\mathrm{H} 1$ in this study is accepted.

Table 4. Regression Weights: (Group number 1 - Default model)

\begin{tabular}{|c|c|c|c|c|c|c|c|}
\hline & & & Estimate & S.E. & C.R. & $\mathbf{P}$ & Label \\
\hline KK & $<--$ & KA &,- 021 & 156 & 2,136 & ,022 & par_5 \\
\hline KK & $<--$ & EBI & -092 & ,047 & 1,974 & ,048 & par_6 \\
\hline
\end{tabular}


Agus Putranto, M. Trihudiyatmanto

\section{Moderation Test}

Analysis of the results of data processing at the SEM moderation stage was carried out by performing a suitability test and statistical test. The results of data processing for the full model SEM analysis are shown in the following figure:

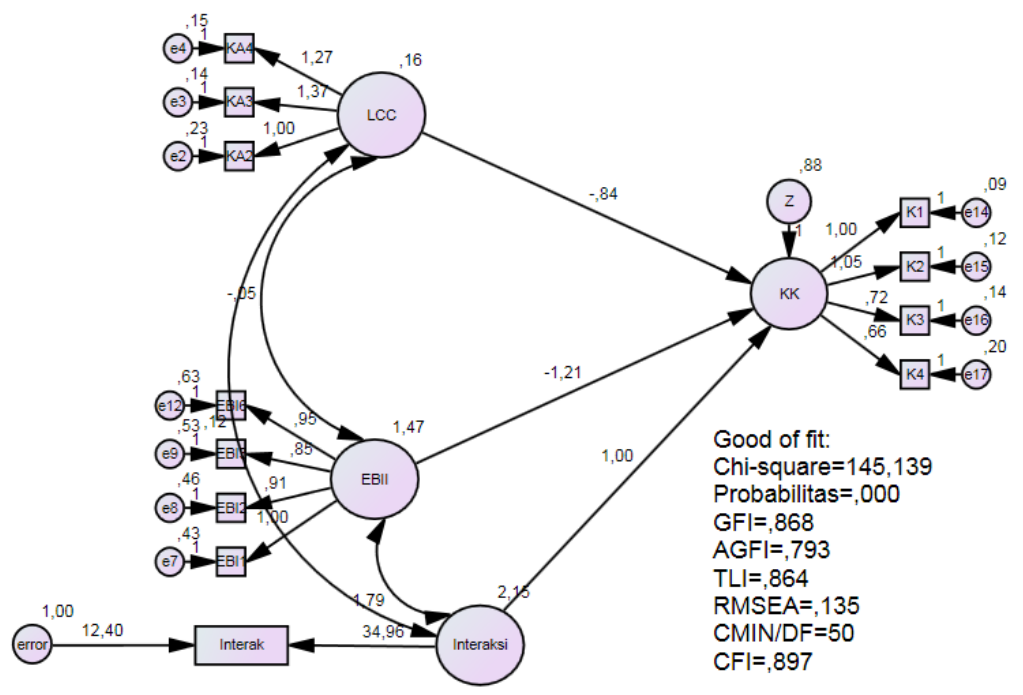

The probability value is still below 0.05 , which is equal to 0,000 which indicates that the model is not fit, but because the Chi square value is smaller than required, the model can be used for further testing (Ghozali, 2017).

The interaction variable between Adaptability and Islamic business ethics has a significant effect on business performance with a parameter coefficient value of 1.804 with a probability of 1 or significant at 0.10 . So it can be concluded that the variable Islamic business ethics is a moderating variable or a variable that moderates the relationship between adaptability and business performance.

H3: Islamic Business Ethics moderate the relationship between Adaptability to

Business Performance at BMT Marhamah Wonosobo Regency. 
The Role Of Islamic Business Ethics In The ...

\section{Effect of Adaptability on Business Performance}

From the results of the research above, the estimation for testing the Adaptability to Business Performance shows a CR value of 2.136 and a probability of 0.22 . The two values obtained meet the requirements for $\mathrm{H} 1$ acceptance, namely the CR value of 2.136 which is smaller than 1.96 and the probability is greater than 0.05 . Thus it can be concluded that the Adaptability has a positive effect on Business Performance in the BMT Marhamah Wonosobo Regency, which means that if the Adaptation Ability is good, the performance will be maximized and vice versa.

\section{The Effect of Islamic Business Ethics on Business Performance}

From the results of the above research, the estimation for testing Islamic Business Ethics on Business Performance shows that the CR value is 1.974 and with a probability of 0.48 . The two values obtained meet the requirements for $\mathrm{H} 1$ acceptance, namely the $\mathrm{CR}$ value of 1.974 which is greater than 1.96 and the probability of 0.048 which is smaller than 0.05 . Thus it can be concluded that Islamic Business Ethics has a positive effect on business performance in the BMT Marhamah business in Wonosobo Regency, which means that if Islamic Business Ethics is good, the performance will be maximized and vice versa.

\section{Islamic Business Ethics Moderate the Effect of Adaptability on Business Performance}

From the results of the above research shows an estimate that Islamic business ethics moderates the relationship between internal adaptability to the Business Performance of BMT Marhamah in Wonosobo Regency. With a parameter coefficient value of 1.804 with a probability of 1 or significant at 0.10 . So it can be concluded that the variable Islamic business ethics is a moderating variable or a variable that moderates the relationship between adaptability and business performance. 
Agus Putranto, M. Trihudiyatmanto

\section{Conclusion}

H1: Adaptability has a positive effect on business performance

Hypothesis testing conducted proves that there is no directional influence between adaptability and business performance. This is in line with the research of Susilo Toto Raharjo (2016), Felix Andhy Winata, at. el (2018) and Azalila Noor Malasari (2019) who say that Adaptability has a positive effect on Business Performance.

$\mathrm{H} 2$ : Islamic business ethics has a positive effect on business performance

Hypothesis testing conducted proves that there is a unidirectional influence between Islamic business ethics and business performance. This is in line with the research of Risahayu Umiyaroh, Tetra Hidayati, Rabiatul Adawiyah (2019), Rizkiana Nur A (2018), Muhammad Majid Himawan (2016) which states that Islamic business ethics has a positive effect on business performance.

H3: Adaptability has a positive effect on business performance with Islamic business ethics as a moderating variable.

Hypothesis testing conducted proves that the effect of adaptability has a positive effect on business performance with Islamic business ethics as a moderating variable. This is in line with the research of Tri Ramadhan Aji Saputra (2015) which states that Adaptability has a positive effect on Business Performance with Islamic business ethics as a moderating variable.

Given the above limitations, it is hoped that future research will:

a) In future research, it is expected that more variables that affect business performance will be used in addition to Adaptability and Islamic business ethics.

b) The number of respondents in the sample between men and women is balanced.

c) Convincing efforts to fill out the questionnaire in accordance with the actual facts. 
The Role Of Islamic Business Ethics In The ...

\section{References}

A, R. N. (2018). The influence of internal locus of control on employee performance with Islamic work ethics as a moderating variable (Studies on Employees at Bank Syariah Mandiri Branch of Purwokerto).

http://repository.umy.ac.id/bitstream/handle/123456789/1619

4/k. NASKAH ].pdf?sequence=11\&isAllowed=y

Ferdinand, A. T. (2006). Management Research Methods (II). Mr. Undip.

Malasari, A. N. (2019). "The effect of adaptability and innovative work behavior on innovative output with environmental dynamics as a moderating variable (Studies on Micro, Small and Medium Enterprises in Semarang City). Unnes Semarang.

Purwanto, H., \& Trihudiyatmanto, M. (2018). Pengaruh Intensi Berwirausaha , Orientasi Kewirausahaan Terhadap Kinerja Usaha dengan Motivasi Sebagai Variabel Intervening pada Sentra UMKM Carica di Wonosobo. Journal of Economic, Management, Accounting and Technology (JEMATech), 1(1), 42-52.

Trihudiyatmanto, M., \& Purwanto, H. (2018). Pengaruh Motivasi, Kompetensi dan Orientasi Berwirausaha Terhadap Kinerja Usaha pada Sentra Umkm Pande Besi di Wonosobo. In Journal of Economic, Management, Accounting and Technology (Vol. 1). https://doi.org/10.32500/jematech.v1i1.210

Umiyaroh, R., Hidayati, T., \& Adawiyah, R. (2019). The influence of internal locus of control on employee performance with Islamic work ethics as a moderating variable. Mulawarman Journal of Economics (JIEM), 3(3).

Winata, F. A., ., \& El, A. (2018). The influence of relationship quality and adaptability to the environment that affect competitive advantage and its implications for company performance (Study at PT. Aga Pratama). MM UNDIP Thesis Journal. 
Agus Putranto, M. Trihudiyatmanto

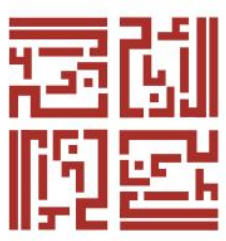

AL-ARBAH | 36 